University of Nebraska - Lincoln

DigitalCommons@University of Nebraska - Lincoln

Publications from USDA-ARS / UNL Faculty

U.S. Department of Agriculture: Agricultural

Research Service, Lincoln, Nebraska

4-10-2015

Registration of A/BN641 and RN642 waxy Grain Sorghum Genetic Stocks

M. K. Yerka

USDA-ARS, melinda.yerka@ars.usda.gov

J. J. Toy

USDA-ARS, John.Toy@ars.usda.gov

Deanna L. Funnell-Harris

USDA-ARS, Deanna.Funnell-Harris@ars.usda.gov

Scott E. Sattler

USDA-ARS, Scott.Sattler@ars.usda.gov

J. F. Pedersen

USDA-ARS, jpedersen1@unl.edu

Follow this and additional works at: https://digitalcommons.unl.edu/usdaarsfacpub

Yerka, M. K.; Toy, J. J.; Funnell-Harris, Deanna L.; Sattler, Scott E.; and Pedersen, J. F., "Registration of A/ BN641 and RN642 waxy Grain Sorghum Genetic Stocks" (2015). Publications from USDA-ARS / UNL Faculty. 1859.

https://digitalcommons.unl.edu/usdaarsfacpub/1859

This Article is brought to you for free and open access by the U.S. Department of Agriculture: Agricultural Research Service, Lincoln, Nebraska at DigitalCommons@University of Nebraska - Lincoln. It has been accepted for inclusion in Publications from USDA-ARS / UNL Faculty by an authorized administrator of DigitalCommons@University of Nebraska - Lincoln. 


\title{
Registration of A/BN641 and RN642 waxy Grain Sorghum Genetic Stocks
}

\author{
M. K. Yerka, ${ }^{*}$ J. J. Toy, D. L. Funnell-Harris, S. E. Sattler, and J. F. Pedersen
}

\begin{abstract}
Loss-of-function mutations in the granule-bound starch synthase gene result in an endosperm with a waxy appearance and a near absence of starch amylose. Three waxy grain sorghum [Sorghum bicolor (L.) Moench] lines, AN641 (Reg. No. GS-741, PI 672150), BN641 (Reg. No. GS-742, PI 672151), and RN642 (Reg. No. GS-743, PI 672152) were developed jointly by the USDA-ARS and the Agricultural Research Division, Institute of Agriculture and Natural Resources, University of Nebraska, and were released in June 2014. AN641 and BN641 have the waxy ${ }^{b}\left(w x^{b}\right)$ allele and are near-isogenic to 'Wheatland'. RN642 has the waxy ${ }^{a}\left(w x^{a}\right)$ allele and is nearisogenic to 'Tx430'. Release of these lines with cytoplasmic male-sterile (A), maintainer (B), and fertility restorer (R) fertility reactions to $A_{1}$ cytoplasm facilitates the production and evaluation of interallelic $\left(w x^{b} \times w x^{a}\right)$ waxy and heterowaxy $\left[w x^{b} \times\right.$ wild-type $(\mathrm{WT})$ and WT $\left.\times w x^{a}\right]$ hybrids as a source of low-amylose starch for the ethanol and food industries.
\end{abstract}

This document is a U.S. government work and is not subject to copyright in the United States.

Copyright $\odot$ Crop Science Society of America. All rights reserved. No part of this periodical may be reproduced or transmitted in any form or by any means, electronic or mechanical, including photocopying, recording, or any information storage and retrieval system, without permission in writing from the publisher. Permission for printing and for reprinting the material contained herein has been obtained by the publisher.

Journal of Plant Registrations 9:258-261 (2015).

doi:10.3198/jpr2014.10.0075crgs

Received 24 Oct. 2014. Accepted 1 Feb. 2015.

Registration by CSSA.

5585 Guilford Rd., Madison, WI 53711 USA

*Corresponding author (melinda.yerka@ars.usda.gov)
$\mathrm{I}$ N GRAIN ETHANOL PRODUCTION, starch amylose increases viscosity and forms complexes with lipids, which restrict access of hydrolytic enzymes to starch molecules and lengthen fermentation times (Sharma et al., 2007; Wang et al., 2008; Wu et al., 2008; Wu et al., 2010; Yan et al., 2011). The food industry uses low-amylose starch to reduce the viscosity of pastes and to increase the shelf life of breads, cakes, and pastes (Wang and Copeland, 2013). Additional sources of starch with a range of amylose contents are sought for customized product development, to alter the glycemic index of food, or to confer desired rheological properties (Sang et al., 2008; Zhu, 2014). Common sources of low-amylose starch include waxy corn (Zea mays L.), wheat (Triticum aestivum L.), rice (Oryza sativa L.), and potato (Solanum tuberosum L.). Sorghum [Sorghum bicolor (L.) Moench] originated in northeast Africa and is adapted to semiarid environments. Development of grain sorghum parent lines suitable for waxy and heterowaxy (having one waxy and one wild-type [WT] allele) sorghum hybrid production provides an opportunity to produce low-amylose starch in dryland and irrigated cropping systems where decreased water use is desirable.

Amylose is synthesized by granule-bound starch synthase (GBSS) (Denyer et al., 2001), encoded by the $W x$ gene (Sb10 g002140) in sorghum. In sorghum, two loss-of-function mutations in $W x$ were identified and characterized (Pedersen et al., 2005; Sattler et al., 2009). The $w x^{a}$ allele contained a large DNA insertion within the third exon, and both GBSS protein and enzyme activity were undetectable in the grain (Pedersen et al., 2005; Sattler et al., 2009). The $w x^{b}$ allele contained a missense mutation, resulting in substitution of a histidine for glutamine at amino acid 268 . The GBSS protein was present, but enzyme activity was reduced by $>75 \%$ in $w x^{b}$ grain relative to wild-type (Pedersen et al., 2005; Sattler et al., 2009). Thus, while amylose content of WT grain ranges from 20 to $50 \%$, amylose content of waxy grain ranges from 0 to $5 \%$ (Rooney and Serna-Saldivar, 2000; Zhu, 2014). Heterowaxy grain has intermediate amylose

M.K. Yerka, J.J. Toy, D.L. Funnell-Harris, S.E. Sattler, and J.F. Pedersen (retired), USDA-ARS, Grain, Forage, and Bioenergy Research Unit, 137 Keim Hall, East Campus, Univ. of Nebraska-Lincoln, Lincoln, NE 685830937.

Abbreviations: GBSS, granule-bound starch synthase; WT, wild-type. 
content, depending on the dose of $w x$ alleles in the triploid endosperm (Ring et al., 1989).

The USEPA announced that ethanol produced from sorghum grain qualifies as an advanced biofuel (USEPA, 2012), which has increased the ethanol industry's interest in sorghum. Despite the benefits of low-amylose starch for the ethanol and food industries, wx hybrids historically have been associated with yield drag relative to WT hybrids (Rooney et al., 2005). Using two different $w x$ alleles in a hybrid background should minimize the effects of recessive deleterious genes linked to the $W x$ locus. Commercial hybrid sorghum seed production requires the use of cytoplasmic male-sterile (A) lines, maintainer (B) lines, and restorer ( $\mathrm{R}$ ) lines, capable of restoring male fertility in $\mathrm{F}_{1}$ hybrids. The $w x^{b}$ and $w x^{a}$ alleles were introgressed into sorghum cultivars Wheatland and Tx430, respectively, to develop A, B and R lines-AN641 (Reg. No. GS-741, PI 672150), BN641 (Reg. No. GS-742, PI 672151), and RN642 (Reg. No. GS-743, PI 672152) - that will facilitate production and evaluation of waxy and heterowaxy hybrids.

\section{Materials and Methods}

The waxy sorghum lines near-isogenic to Wheatland (Brown et al., 1936) and Tx430 (Miller 1984) were developed through the introgression of $w x$ alleles into genetically (nuclear) malesterile 3 (ms3) versions of BWheatland and RTx430 (Pedersen et al., 1997) by crossing with waxy lines BTxARG-1 $\left(w x^{b}\right)$ and RTx2907 $\left(w x^{a}\right)$ (Pedersen et al., 2005), respectively. $\mathrm{F}_{1}$ progeny of the ms 3 BWheatland $\times$ BTxARG-1 $\left(w x^{b}\right)$ cross were selfpollinated. $\mathrm{F}_{2}$ progeny homozygous for $m s 3$ and segregating for $w x$ were backcrossed with WT BWheatland. The $\mathrm{BC}_{1}$ progeny was self-pollinated, and $\mathrm{BC}_{1} / \mathrm{S}_{1}$ individuals homozygous for $m s 3$ and segregating for $w x$ were backcrossed with WT BWheatland. A total of four backcrosses were made in this manner. The $\mathrm{BC}_{4} /$ $\mathrm{S}_{2}$ was screened for $w x M s 3 M s 3$ progeny, which were used in paired crosses for six generations to develop AN641 and BN641 as follows. The $\mathrm{BC}_{4} / \mathrm{S}_{2}$ was crossed to the $\mathrm{A}_{1}$ cytoplasm source AWheatland to generate AWheatland $\times \mathrm{BC}_{4} / \mathrm{S}_{2}$ progeny (the AN641 experimental line) and simultaneously self-pollinated to generate the $\mathrm{BC}_{4} / \mathrm{S}_{3}$ (the $\mathrm{BN} 641$ experimental line). The BN641 experimental line was crossed to the AN641 experimental line and subsequently self-pollinated until the $\mathrm{BC}_{4} / \mathrm{S}_{8}$ generation, when the finished AN641 and BN641 line (synonym $=w x^{b} \mathrm{~A} /$ BWheatland) was released. Similar methods used to develop BN641 were used to develop progeny from the $m s 3$ RTx430 $\times$ RTx2907 $\left(w x^{a}\right)$ cross into RN642 (synonym $=w x^{a}$ RTx430). Pedigree information for AN641, BN641 and RN642 is presented in Table 1. Allele-specific primers (Sattler et al., 2009) and iodine staining (Pedersen et al., 2004) were used to verify that A/BN641 and RN642 are homozygous for their respective $w x$ alleles.
BN641 and RN642 were evaluated for agronomic performance and yield on a per se basis in field trials at Mead, NE, in 2007 and 2008 (Sharpsburg silty clay loam; fine smectitic, mesic Typic Agriudoll); and at Lincoln, NE, in 2008 (Kennebec silt loam; fine-silty, mixed, superactive, mesic Cumulic Hapludoll) (three environments total). Wildtype BWheatland and RTx430 were included for comparison. The lines (four entries total) were sown at 120 seeds per row $\left(240,000\right.$ seeds $\left.\mathrm{ha}^{-1}\right)$ delivered by a precision vacuum planter in the third week of May. Plots consisted of two 6.6-m rows spaced $76 \mathrm{~cm}$ apart. For all locations, nitrogen fertilizer was applied at $112 \mathrm{~kg} \mathrm{ha}^{-1}$ before planting. Atrazine [6-chloro-n-ethyl$N^{\prime}$ (1-methylethyl)-1,3,5-triazine-2,4,diamine] was applied at $1.12 \mathrm{~kg} \mathrm{ha}^{-1}$ immediately after planting, followed by an application of quinclorac (3,7-dichloro-8-quinolinecarboxylic acid) and atrazine at $0.37 \mathrm{~kg} \mathrm{ha}^{-1}$ and $0.56 \mathrm{~kg} \mathrm{ha}^{-1}$, respectively, 4 wk after planting at Mead 2007. Atrazine $\left(0.37 \mathrm{~kg} \mathrm{ha}^{-1}\right)$ and alachlor [2-Chloro- $N$-(2,6-diethylphenyl)- $N$-(methoxymethyl) acetamide] were applied at $1.25 \mathrm{~kg}$ a.i. ha ${ }^{-1} 2 \mathrm{wk}$ after planting at Mead 2008. Supplemental irrigation $(3.8 \mathrm{~cm})$ was applied at Mead via overhead sprinklers on 29 June, 5 July, 16 July, and 26 July 2007. Irrigation $(2.5 \mathrm{~cm})$ was applied on 30 July and 5 September at Mead in 2008; $3.8 \mathrm{~cm}$ was applied 15 August. No supplemental irrigation was applied at Lincoln. Baythroid [Cyano(4-fluoro-3-phenoxyphenyl)methyl-3-(2,2-dichloroethenyl)-2,2-dimethyl-cyclopropanecarboxylate] was applied at $0.3 \mathrm{~kg}$ a.i. ha ${ }^{-1}$ on 1 August at Mead 2008 to control for grasshoppers (Orthoptera).

The experimental design was a randomized complete block with four replicates. Agronomic characters recorded included field emergence (plants $\mathrm{m}^{-1}$ ) approximately 4 wk post-planting, days to $50 \%$ anthesis, and height $(\mathrm{cm})$ at the top of the mature panicle. Grain was hand-harvested and air-dried to constant mass, threshed, weighed, and adjusted to $145 \mathrm{~g} \mathrm{~kg}^{-1}$ moisture before yield analysis $\left(\mathrm{kg} \mathrm{ha}^{-1}\right)$. Test weight $\left(\mathrm{kg} \mathrm{hL}^{-1}\right)$ also was recorded. Data were subjected to analysis of variance in PROC MIXED of SAS version 9.2 (SAS Institute, 2012) to generate least squares (LS) means and $P$ values. Entry was considered a fixed effect and environment, replicate within environment, and environment $\times$ entry were considered random in determining the effect of entry on the response variables measuring agronomic performance and yield. LS means were separated at $P=0.05$ using Fisher's Protected LSD test.

\section{Characteristics}

Complete comparisons of agronomic performance are presented in Table 2. BN641 resembles BWheatland, as it has a purple necrotic lesion color, no awns, a red caryopsis, juicy culms, and no tannins in the grain, and it does not restore fertility in $\mathrm{A}_{1}$ cytoplasm. Averaged over environments, BN641 field emergence, days to $50 \%$ anthesis, and test weight were

Table 1. Pedigrees, fertility reactions, and endosperm type of waxy sorghum genetic stocks.

\begin{tabular}{|c|c|c|c|c|}
\hline Entry & Synonym & Pedigree & Fertility reactiont & Endosperm \\
\hline AN641 & $w x^{b}$ AWheatland & $\mathrm{BC}_{6}\left[\right.$ AWheatland $\times w x^{b}$ BWheatland] & A & waxy \\
\hline BN641 & $w x^{b}$ BWheatland & $\mathrm{S}_{8}\left[\left(\mathrm{~F}_{2} m s 3\right.\right.$ BWheatland $\times \mathrm{B}$ TxARG-1 $\left.\left(w x^{b}\right)\right) /$ BWheatland $\left.\mathrm{BC}_{4}\right]$ & B & waxy \\
\hline RN642 & $w x^{a} \mathrm{RT} \times 430$ & $\mathrm{~S}_{5}\left[\left(\mathrm{~F}_{2} m s 3 \mathrm{RT} \times 430 \times \mathrm{RT} \times 2907\left(w x^{a}\right)\right) / \mathrm{RT} \times 430 \mathrm{BC}_{4}\right]$ & $\mathrm{R}$ & waxy \\
\hline
\end{tabular}

† Fertility reaction to $A_{1}$ cytoplasmic male-sterile cytoplasm: $A / B=$ male-sterile/maintainer pair, $R=$ fertility restorer. 
Table 2. Entry, agronomic performance, and yield of near-isogenic waxy and wild-type sorghum genetic stocks. Data were pooled over three environments: Mead, NE, in 2007 and 2008; and Lincoln, NE, in 2007.

\begin{tabular}{|c|c|c|c|c|c|c|}
\hline \multirow[b]{2}{*}{ Entry } & \multirow[b]{2}{*}{ Endosperm } & Emergence & $50 \%$ anthesis & Height & Yield‡ & Test weight \\
\hline & & \multicolumn{5}{|c|}{ Meant } \\
\hline & & plants $\mathrm{m}^{-1}$ & $d$ & $\mathrm{~cm}$ & $\mathrm{~kg} \mathrm{ha}^{-1}$ & $\mathrm{~kg} \mathrm{hL}^{-1}$ \\
\hline \multicolumn{7}{|l|}{ B-lines } \\
\hline BWheatland & wild-type & $20 a$ & $76 a$ & $109 a$ & $6200 \mathrm{a}$ & $66 a$ \\
\hline BN641 & waxy & $20 a$ & $74 a$ & $120 \mathrm{~b}$ & 6942 b & $69 a$ \\
\hline \multicolumn{7}{|l|}{ R-lines } \\
\hline RTx430 & wild-type & $20 a$ & $71 \mathrm{a}$ & $130 \mathrm{a}$ & $6702 a$ & $60 a$ \\
\hline RN642 & waxy & $20 \mathrm{a}$ & $73 a$ & $138 \mathrm{~b}$ & $6717 a$ & $59 a$ \\
\hline $\mathrm{LSD}_{0.05}$ & & 2.3 & 5.1 & 4.2 & 621 & 4.6 \\
\hline
\end{tabular}

† Means with the same letter within columns and $\mathrm{B}$ or $\mathrm{R}$ fertility reactions do not differ at $P=0.05$.

₹ Grain yield was adjusted to $145 \mathrm{~g} \mathrm{~kg}^{-1}$ moisture before analysis.

similar to BWheatland, but BN641 was taller $(120 \mathrm{~cm}$ vs. 109 $\mathrm{cm}, P<0.01)$, and yielded more grain $\left(6942 \mathrm{~kg} \mathrm{ha}^{-1} \mathrm{vs.} 6200 \mathrm{~kg}\right.$ $\left.\mathrm{ha}^{-1}, P=0.02\right)$ than BWheatland.

RN642 resembles RTx430, as it has purple necrotic lesion color, no awns, a translucent white caryopsis, yellow endosperm, juicy culms, and no tannins in the grain, and it restores fertility in $\mathrm{A}_{1}$ cytoplasm. RN642 field emergence, days to $50 \%$ anthesis, grain yield, and test weight were similar to RTx430, but RN642 was taller $(138 \mathrm{~cm}$ vs. $130 \mathrm{~cm}, P<0.01)$ than RTx 430 .

The waxy trait in sorghum lines and hybrids has been associated with yield drag (Rooney et al., 2005), which Jampala et al. (2012) suggested could be overcome by focusing breeding efforts to eliminate deleterious alleles linked to the $W x$ locus. Yield of BN641 was greater than that of BWheatland, and yield of RN642 did not differ statistically from RTx430; thus, both the $w x^{a}$ and $w x^{b}$ alleles were not associated with reduced yield in their respective lines. It should be noted that BN641 and RN642 were taller than the WT. The combining abilities of AN641 and RN642 are currently unknown.

AN641, BN641 and RN642 are three-dwarf, combineheight, photoperiod-insensitive lines with similar agronomic performance, flowering time, and grain yield to Wheatland and Tx430, respectively. These traits are desirable for commercial production of waxy and heterowaxy grain sorghum hybrids in temperate regions of the world. The drought tolerance of sorghum in particular may be used to produce low-amylose starch in both dryland and irrigated systems where reduced water use is desired. A/B and R fertility reactions facilitate crossing with each other or with additional waxy and WT lines of similar maturity (71 to $76 \mathrm{~d}$ ) to breed for local adaptation and to expand sources of low-amylose starch for the ethanol and food industries.

\section{Conclusions}

Release of A/BN641 and RN642 makes available two different $w x$ alleles of sorghum, $w x^{a}$ and $w x^{b}$, with $\mathrm{A} / \mathrm{B}$ and $\mathrm{R}$ fertility reactions, respectively. Neither line demonstrated reduced field emergence or yield relative to their corresponding parental line in field trials in three environments. Each may be crossed with one another or with other waxy or WT lines to generate waxy and heterowaxy hybrids useful for the production of low-amylose starch.

\section{Availability}

Seed of these sorghum genetic stocks will be maintained and distributed by the USDA-ARS, Grain, Forage, and Bioenergy Research Unit, Department of Agronomy, University of Nebraska, Lincoln, Nebraska 68583-0937, and will be provided without cost to each applicant on written request. Genetic material of this release has been deposited in the National Plant Germplasm System, where it will be immediately available for research purposes, including development and commercialization of new cultivars. It is requested that appropriate recognition be made if this germplasm contributes to the development of new breeding materials.

\section{Acknowledgments}

We thank Dr. William Rooney of Texas A\&M University for providing the original $w x$ source lines used in the development of these genetic stocks. We thank Patrick O’Neill for his technical assistance with statistical analysis of data presented in this manuscript. Mention of trade names or commercial products in this article is solely for the purpose of providing specific information and does not imply recommendation or endorsement by the US Department of Agriculture. This article is in the public domain and not copyrightable. It may be freely reprinted with customary crediting of source. The USDA is an equal opportunity provider and employer.

\section{References}

Brown, H.B., J.A. Clark, E.F. Gaines, H.K. Hayes, W.J. Morse, J.H. Parker, T.R. Stanton, G.H. Stringfield, and M.A. McCall. 1936. Varietal standardization and registration. J. Am. Soc. Agron. 28:1027.

Denyer, K., P. Johnson, S. Zeeman, and A.M. Smith. 2001. The control of amylose synthesis. J. Plant Physiol. 158:479-487. doi:10.1078/0176-161700360

Jampala, B., W.L. Rooney, G.C. Peterson, S. Bean, and D.B. Hays. 2012. Estimating the relative effects of the endosperm traits of waxy and high protein digestibility on yield in grain sorghum. Field Crops Res. 139:5762. doi:10.1016/j.fcr.2012.09.021

Miller, F.R. 1984. Registration of RTx430 sorghum parental line. Crop Sci. 24:1224. doi:10.2135/cropsci1984.0011183X002400060074x

Pedersen, J.F., S.R. Bean, D.L. Funnell, and R.A. Graybosch. 2004. Rapid iodine staining techniques for identifying the waxy phenotype in sorghum grain and waxy genotype in sorghum pollen. Crop Sci. 44:764-767.

Pedersen, J.F., S.R. Bean, R.A. Graybosch, S.H. Park, and M. Tilley. 2005. Characterization of waxy grain sorghum lines in relation to granule-bound starch synthase. Euphytica 144:151-156. doi:10.1007/s10681-005-5298-5

Pedersen, J.F., J.J. Toy, and B.E. Johnson. 1997. Registration of 21 sorghum genetic stocks with ms3ms3. Crop Sci. 37:1410-1411. doi:10.2135/cropsci 1997.0011183X003700040098x

Ring, S.H., J.O. Akingbala, and L.W. Rooney. 1989. A study of factors affecting amylose content of sorghum determined by an automated method. Starke 41:457-461. doi:10.1002/star.19890411204 
Rooney, W.L., S. Aydin, and L.C. Kuhlman. 2005. Assessing the relationship between endosperm type and grain yield potential in sorghum (Sorghum bicolor L. Moench). Field Crops Res. 91:199-205. doi:10.1016/j. fcr.2004.07.011

Rooney, W.L., and S.O. Serna-Saldivar. 2000. Sorghum. In: K. Kulp and J.G. Ponte, Jr., editors, Handbook of cereal science and technology. 2nd ed. Marcel Dekker, New York. p. 149-176.

SAS Institute. 2012. The SAS system for Windows. V. 9.2. SAS Inst., Cary, NC.

Sang, Y., S. Bean, P.A. Seib, J. Pedersen, and Y.C. Shi. 2008. Structure and functional properties of sorghum starches differing in amylose content. J. Agric. Food Chem. 56:6680-6685. doi:10.1021/jf800577x

Sattler, S.E., J. Singh, E.J. Haas, L. Guo, G. Sarath, and J.F. Pedersen. 2009. Two distinct waxy alleles impact the granule-bound starch synthase in sorghum. Mol. Breed. 24:349-359. doi:10.1007/s11032-009-9296-5

Sharma, V., K.D. Rausch, M.E. Tumbleson, and V. Singh. 2007. Comparison between granular starch hydrolyzing enzyme and conventional enzymes for ethanol production from maize starch with different amylose:amylopectin ratios. Starke 59:549-556. doi:10.1002/star.200700631

USEPA. 2012. Supplemental determination for the renewable fuels produced under the final RFS2 program from grain sorghum. Fed. Regist. 77:7459274607. https://federalregister.gov/a/2012-30100 (accessed 27 June 2013).
Wang, D., S.R. Bean, J. McLaren, P. Seib, R. Madl, M. Tuinstra, Y. Shi, M. Lenz, X. Wu, and R. Zhao. 2008. Grain sorghum is a viable feedstock for ethanol production. J. Ind. Microbiol. Biotechnol. 35:313-320. doi:10.1007/s10295-008-0313-1

Wang, S., and L. Copeland. 2013. Molecular disassembly of starch granules during gelatinization and its effect on starch digestibility: A review. Food Funct. 4:1564-1580. doi:10.1039/c3fo60258c

Wu, X., B. Jampala, A. Robbins, D.B. Hays, Y. Shuping, X. Feng, W.L. Rooney, Y. Shi, and D. Wang. 2010. Ethanol fermentation performance of grain sorghums (Sorghum bicolor) with modified endosperm matrices. J. Agric. Food Chem. 58:9556-9562. doi:10.1021/jf101555d

Wu, X., R. Zhao, L. Liu, S. Bean, P. Seib, J. McLaren, R. Madl, M. Tuinstra, M. Lenz, and D. Wang. 2008. Effects of growing location and irrigation on attributes and ethanol yields of selected grain sorghums. Cereal Chem. 85:495-501. doi:10.1094/CCHEM-85-4-0495

Yan, S., X. Wu, S.R. Bean, J.F. Pedersen, T.T. Tesso, Y.R. Chen, and D. Wang. 2011. Evaluation of waxy grain sorghum for ethanol production. Cereal Chem. 88:589-595. doi:10.1094/CCHEM-04-11-0056

Zhu, F. 2014. Structure, physiochemical properties, modifications, and uses of sorghum starch. Compr. Rev. Food Sci. Food Saf. 13:597-610. doi:10.1111/1541-4337.12070 